\title{
Association of FTO rs1421085 single nucleotide polymorphism with fat and fatty acid intake in Indonesian adults
}

\author{
Athraa Alaulddin Al-Jawadi ${ }^{1 \dagger}$, Lidwina Priliani ${ }^{2 \dagger}$, Sukma Oktavianthi ${ }^{2 \dagger}$, Clarissa A. Febinia ${ }^{2 \dagger}$, Mulianah Daya ${ }^{3}$, I
} Made Artika ${ }^{1,2}$ and Safarina G. Malik ${ }^{2^{*}}$ (D)

\begin{abstract}
Objective: Recent studies showed that genetic polymorphisms in the fat mass and obesity-associated gene (FTO) were associated with obesity and dietary intake. In this study of 71 adults in Jakarta, Indonesia, we investigated FTO rs1421085 association with body mass index (BMI), macronutrient intake, and fatty acid intake. The association was evaluated using linear regression analyses assuming co-dominant, dominant, recessive, over-dominant, and additive genetic models.

Results: Only individuals with the CC genotype had a considerably higher BMI $(p<0.001)$, which indicates a recessive genetic trait, but the incidence for this genotype is low (68 TT +TC vs. 3 CC). Individuals with the minor C allele had an estimated increase of fat intake by $3.45-4.06 \%$ across various genetic models (dominant: $p<0.010$, overdominant: $p<0.030$, additive: $p<0.010$ ). Subjects with TC/CC genotypes had increased dietary monounsaturated fatty acid (MUFA; $1.14 \%, p=0.046$ ) and saturated fatty acid (SAFA; $2.06 \%, p=0.023$ ) intakes, compared to those with the TT genotype. In conclusion, our study provided evidence for the association between FTO rs 1421085 risk allele with higher BMI and individual preferences for consuming more fat, MUFA, and SAFA. This study highlights the important role of FTO gene in food preference, and its influence on body weight.
\end{abstract}

Keywords: FTO, rs1421085, Fatty acid, Fat intake, Obesity, Indonesia

\section{Introduction}

WHO reported that $13 \%$ of the global population of adults were obese in 2016 [1], and it is projected that 1 in 5 adults will be obese in 2025 [2]. Obesity manifestation is a complex interaction between overnutrition, sedentariness, and genetic factors [3]. Obesity in Indonesia has increased significantly between 2007 (10.5\%) and 2018 $(21.8 \%)[4,5]$. There is a growing interest in the genetic

\footnotetext{
*Correspondence: ina@eijkman.go.id

${ }^{\dagger}$ Athraa Alaulddin Al-Jawadi, Lidwina Priliani, Sukma Oktavianthi and

Clarissa A. Febinia contributed equally to this work

${ }^{2}$ Eijkman Institute for Molecular Biology, Ministry of Research

and Technology/National Research and Innovation Agency, Jl.

Diponegoro No. 69, Jakarta 10430, Indonesia

Full list of author information is available at the end of the article
}

predisposition of obesity in Indonesia since mortality due to obesity comorbidities have risen to the nation's top [6-8].

The association between the fat mass and obesity-associated $(F T O)$ and obesity is well-documented, particularly in Caucasian populations, albeit the overall risk is modest [9-15]. Single nucleotide polymorphism (SNPs) in the FTO gene were associated with other obesity traits (e.g., body weight, leptin levels, body fat, waist circumference) [9-13, 15-17]. East and South Asian populations showed comparable associations for common FTO variants (notably rs9939609, rs1558902, and rs1421085) [16-21], but the effect size may vary depending on ethnicity and dietary intake [22, 23]. Concurrent associations between $F T O$ variants, obesity, and dietary intake 
have been noted in several ethnic groups [22-27], including our previous report that FTO rs9939609 TT genotype was associated with obesity and preference for a high-fat diet in adult individuals from Jakarta [28].

Expression of the $F T O$ gene also affects various parts of the brain that regulate energy balance and appetite [3, 29, 30]. FTO mutation rs 9939609 is associated with not only obesity, but also macronutrient intake, that includes: carbohydrates [26, 31], protein [22], polyunsaturated fatty acid (PUFA), and saturated fatty acid (SAFA) [32]. We expect that a similar influence for FTO rs1421085 which has a high linkage disequilibrium with FTO rs9939609 [28]. Several studies reported that FTO rs 1421085 is associated with both obese-related phenotypes and dietary macronutrient intake $[16,17,33]$. In vivo and in vitro model studies showed that FTO rs1421085 can alter the binding of transcriptional repressors in nearby regions, affecting the expression of genes linked to adipocyte thermogenesis and food intake $[34,35]$.

Understanding the interaction between diet and FTO variants in Indonesia may provide valuable insights for obesity management since Indonesian cuisine is naturally fatty, owing to the generous use of coconut milk and palm oil [36-38]. Dietary fat and SAFA intake in Indonesia was the highest among countries across the globe (31.9\% and $20.9 \%$, respectively) [39].

As a continuation of our previous study [28], we performed genotyping for FTO rs1421085 and analyzed its association with obesity and dietary intake. We hypothesize that individuals with the minor risk allele have higher Body Mass Index (BMI), higher fat intake, and distinct fatty acid intake profile (PUFA, monounsaturated fatty acid/MUFA, and SAFA). Our findings provided valuable insights into the influence of the FTO rs1421085 risk allele on BMI and individual preferences for consuming more fat, particularly MUFA and SAFA.

\section{Main text \\ Methods \\ Study design and subjects}

We performed a follow-up case-control genetic association study of $F T O$ rs1421085 on a study population from Daerah Khusus Ibukota (DKI) Jakarta, Indonesia. Study enrollment and collection of informed consent were done as described previously by Daya et al. [28]. We obtained ethical approval from the Medical Research Ethics Committee of the Faculty of Medicine, Universitas Indonesia (No. 1137/UN2/F1/ETIK/2017, protocol number 17-12-1212). We collected age, gender, and residence data at enrollment. We calculated BMI as body weight $(\mathrm{kg})$ per squared height $\left(\mathrm{m}^{2}\right)$. We used the International Obesity Task Force (IOTF) definitions for Asian obesity $\left(\mathrm{BMI} \geq 25 \mathrm{~kg} / \mathrm{m}^{2}\right)$ and non-obesity $\left(\mathrm{BMI}<23 \mathrm{~kg} / \mathrm{m}^{2}\right)[40]$.
We obtained dietary data with questionnaires and calculated dietary intake using NutriSurvey 2007 as previously described $[28,41]$.

\section{Genotyping}

We assessed the quantity and purity of archived DNA samples from our previous study [23] using a Nanodrop-1000 (Perkin Elmer Biosystem, USA). FTO rs1421085 was genotyped using amplification-refractory mutation system polymerase chain reaction (ARMS PCR) as described by Priliani et al. [42] in a GeneAmp PCR System 9700 (Applied Biosystems, USA). PCR products were separated in $2 \%$ agarose gel electrophoresis (Lonza, Basel, Switzerland) and visualized using the Gel Doc XR Imaging System (BioRad, USA). The primer sequences are in Additional file 1: Table S1.

\section{Statistical analysis}

We used R version 4.0.3 for all statistical tests (packages: "stats", "genetics", "Rfit"). Data distribution normality was assessed using the Shapiro-Wilk test. Differences in anthropometric values and dietary intake between obese and non-obese participants were calculated using the unpaired $t$-test for normally distributed variables and the Mann-Whitney $U$ test for non-normal variables. Allele and genotype frequencies were calculated and HardyWeinberg equilibrium test was performed. Association analyses were carried out using either a linear regression analysis (normal variables) or a rank-based linear regression analysis (non-normal variables), adjusted for age and sex (formula: outcome $\sim \mathrm{SNP}+$ age + sex). We assessed the following genetic models: co-dominant (factorial variables: $\mathrm{TT}=0, \mathrm{TC}=1$, and $\mathrm{CC}=2)$, dominant $(\mathrm{TT}=0$, $\mathrm{TC}+\mathrm{TT}=1)$, recessive $(\mathrm{TT}+\mathrm{TC}=0, \quad \mathrm{CC}=1)$, overdominant ( $\mathrm{TT}+\mathrm{CC}=0, \mathrm{TC}=1$ ), and additive (continuous variables: $\mathrm{TT}=0, \mathrm{TC}=1$, and $\mathrm{CC}=2$ ). Upper and lower intervals were calculated at 95\% confidence levels with no adjustments for multiple comparisons. The value of $p<0.05$ was considered statistically significant.

\section{Results}

\section{Baseline characteristics}

Available archived DNA samples consisted of 36 nonobese and 35 obese individuals aged 19-52 years. The difference in gender proportions between the non-obese and obese group was significant (51 female, 29 male, $\mathrm{X}^{2}=7.36, p=0.013$ ). The BMI (median) for the obese and non-obese groups were 31.86 and 20.86 , respectively $(p<0.001)$. Age and dietary parameters are comparable in obese and non-obese samples (all $p>0.05$, Additional file 1: Table S2). 


\section{Genotype and allele distributions}

The FTO rs1421085 genotype and allele distribution are in Table 1 . The minor allele frequency (MAF) was $22 \%$ in total samples $(n=71), 24 \%$ in obese samples $(n=35)$, and $19 \%$ in non-obese samples $(\mathrm{n}=36)$. The genotype distribution did not depart from Hardy-Weinberg equilibrium for total, obese, and non-obese samples (all $p=1$ ). The frequency of $\mathrm{CC}$ genotype was notably low.

\section{Associations of FTO rs 1421085 with BMI and diet}

By evaluating various genetic models, we found several notable associations between FTO rs1421085 with BMI, macronutrient intake, and fatty acid intake (Table 2). BMI is greater by $12.58 \mathrm{~kg} / \mathrm{m}^{2}(p=0.001)$ and $12.38 \mathrm{~kg} / \mathrm{m}^{2}$ $(p<0.001)$ in individuals with the CC genotype under the co-dominant and recessive models, respectively. These individuals also reported lower carbohydrate intake by $7.84 \%(p=0.029)$ and $7.59 \%(p=0.031)$ under the codominant and recessive models, respectively. This data suggests that FTO rs1421085 associations with higher $\mathrm{BMI}$ and lower carbohydrate intake might be a recessive trait that showed only in individuals with $\mathrm{CC}$ genotype. However, we consider these findings inconclusive since the CC genotype frequency was very low $(\mathrm{n}=3)$.

No associations with FTO rs1421085 were found for protein intake, but associations with fat intake (\%) were significant (Table 2). Individuals with TC genotype showed a slightly higher fat intake by $3.87 \%(p=0.018)$ and $3.51 \%(p=0.030)$ under the co-dominant and overdominant models, respectively. The increase was comparable under the dominant (TC+CC: $4.06 \%, p=0.010$ ) and additive model $(3.45 \%, p=0.010)$. Given these findings, FTO rs1421085 association with higher fat intake appeared as a dominant or an additive trait since it was overall stronger in individuals with the minor risk allele.

There were notable associations with MUFA and SAFA intake (Table 2). The association with MUFA was minor; individuals with $\mathrm{TC}+\mathrm{CC}$ genotypes intake were projected with $1.14 \%(p=0.046)$ higher MUFA intake only in the dominant model, whereas the association under

Table 1 FTO rs1421085 genotype and minor allele frequency (MAF), Hardy-Weinberg equilibrium test

\begin{tabular}{llll}
\hline Genotype & $\begin{array}{l}\text { Total, } \mathbf{n}(\%) \\
\mathbf{n}=\mathbf{7 1}\end{array}$ & $\begin{array}{l}\text { Obese, } \mathbf{n}(\%) \\
\mathbf{n}=\mathbf{3 5}\end{array}$ & $\begin{array}{l}\text { Non-obese, } \mathbf{n}(\%) \\
\mathbf{n}=\mathbf{3 6}\end{array}$ \\
\hline $\mathrm{TT}$ & $43(60.6 \%)$ & $20(57.1 \%)$ & $23(63.9 \%)$ \\
$\mathrm{TC}$ & $25(35.2 \%)$ & $13(37.1 \%)$ & $12(33.3 \%)$ \\
$\mathrm{CC}$ & $3(4.2 \%)$ & $2(5.7 \%)$ & $1(2.8 \%)$ \\
MAF & $22 \%$ & $24 \%$ & $19 \%$ \\
p-HWE & 1 & 1 & 1 \\
\hline
\end{tabular}

$M A F$ minor allele frequency, HWE Hardy-Weinberg equilibrium the co-dominant, over-dominant, and additive models were marginal $(p<0.100)$. The co-dominant model showed that individuals with TC and CC genotype had respectively greater SAFA intake by $1.77 \%(p=0.058)$ and $4.49 \%(p=0.043)$ when compared to individuals with TT genotype. The dominant (TC+CC: $2.06 \%, p=0.023$ ) and additive model $(1.96 \%, p=0.011)$ showed comparable results. This data showed that the association with SAFA is likely a dominant or an additive trait, and it is in line with our analysis of fat macronutrient intake.

\section{Discussion}

The rapid increase of obesity incidence and mortality caused by its comorbid conditions have gathered concerns over genetic predispositions to obesity in Indonesia. Recent studies have reported interactions between FTO SNPs with dietary factors [22-32]. There is a scientific need to investigate the link between the FTO gene and dietary intake and further elucidate the underlying mechanisms of their interaction. FTO genetic variants with obesity can differ by ethnicity and dietary preference $[16,22,23,25,28]$. In this study, we performed a genetic association study employing various genetic models to assess the impact of FTO rs1421085 on obesity and dietary preference in individuals residing in Jakarta, Indonesia. We found that FTO rs1421085 is a common mutation in our studied population and the minor risk allele is associated with BMI, higher intake of dietary fat, MUFA, and SAFA.

The minor allele frequency of FTO rs1421085 in our studied population (22\%) is lower than our finding in Balinese (41\%) [42]. The frequency is only slightly higher than Asian populations (13-14\%, excluding South Asians), but lower than South Asian (31\%) and European populations $(42 \%)[43,44]$. Our sample size was admittedly small compared to these studies, but the disparity might also be unique to this specific population due to Indonesia's population diversity [45], natural selection, genetic drift, and mutation [46]. A further study is required to confirm the allelic distribution in Jakarta.

Our assessment of various genetic models indicates that FTO rs1421085 association with BMI is a recessive trait, but the frequency of the heterozygous CC genotype is small. A study employing 84 individuals from Tehran has a similar sample size to ours, and it did not find any association between FTO rs1421085 and BMI [23]. Given that Asian populations have a low frequency of the risk allele, it is likely that a dataset smaller than a few hundred samples might not be sufficient to assess the association.

As expected, we found that FTO rs1421085 was associated with higher dietary fat intake, particularly with SAFA intake. There was also a minor association with MUFA intake. This data supports the findings in an adult 


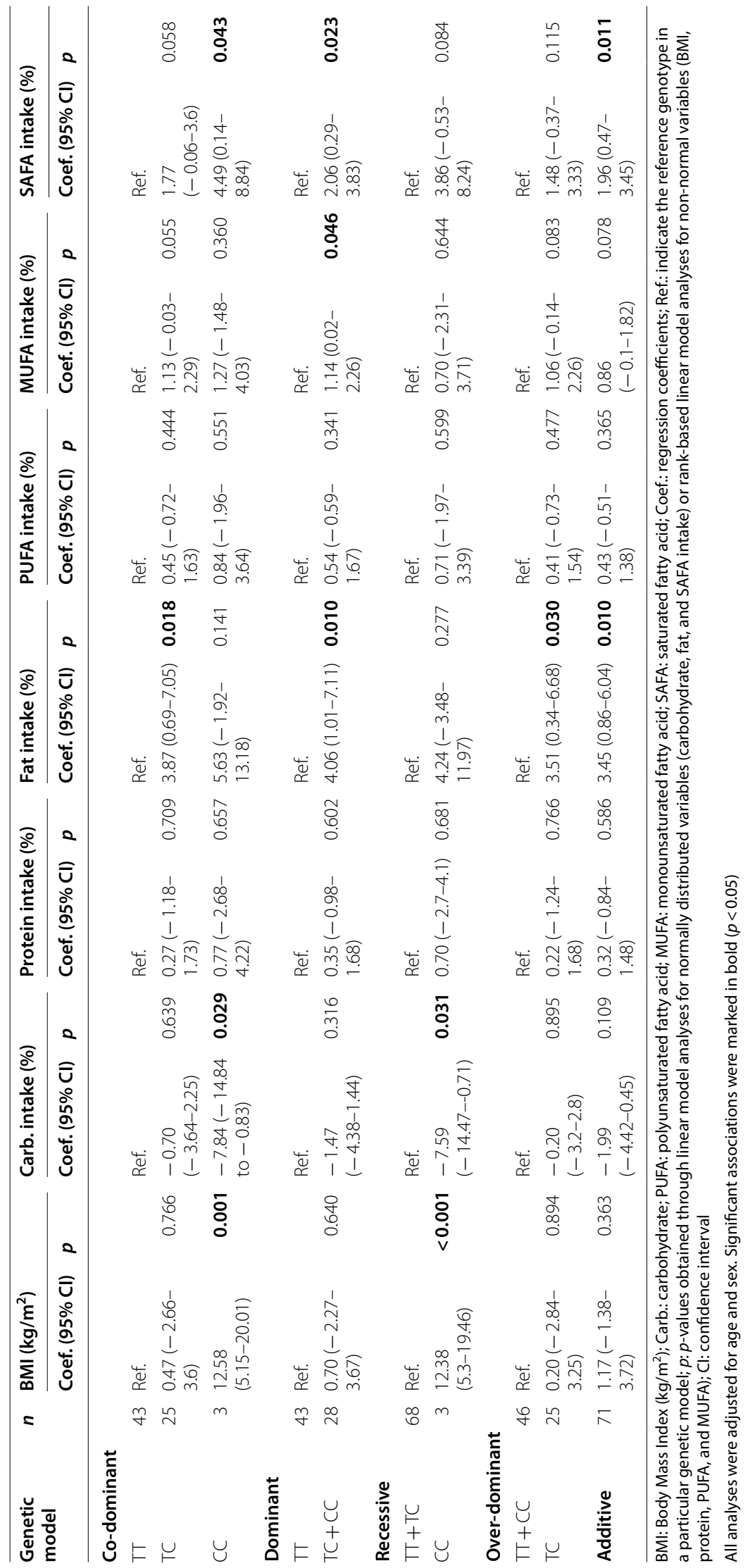


Caucasian population, in which the risk allele of FTO rs1421085 was found associated with perceived hunger, higher intake of high-fat foods, and increased body weight [47]. Our findings support our previous assessment of the FTO rs9939609 risk allele in the same studied population that showed an association to higher fat intake [23]. FTO rs9939609 and rs1421085 have high linkage disequilibrium in our previous study of a Balinese population [29].

Our findings support that FTO gene expression is associated with fatty acid intake (MUFA and PUFA) [48]. FTO rs1421085 can influence the expression of several genes linked to food intake and appetite [34,35], which might explain why we found associations between the risk allele, dietary fat, and SAFA intake under the additive genetic model that imply incremental allelic influence. Notably, FTO can impact signaling pathways that regulate eating behavior, satiety, stress response, mood, and perception of food [29, 30, 49, 50]. Our findings added to this body of knowledge by confirming the association between FTO rs1421085 with dietary fat intake in a small population in Jakarta.

The direction of causality of these associations is not confirmed. However, these findings are compelling evidence that food preference (e.g. dietary fatty acids) can be influenced by the FTO gene and may subsequently affect body weight. Understanding this interaction would be valuable in developing a personalized nutrition strategy to combat obesity.

\section{Conclusions}

FTO rs1421085 TC + CC genotypes were positively associated with BMI, higher dietary fat, MUFA, and SAFA in individuals from Jakarta. Future studies should investigate the mechanisms of actions that underlie the correlation between FTO and dietary preference and its impact on individual weight management.

\section{Limitations}

The sample size for this study was limited; so, a followup study with a larger sample size is required. There might be geographical and gender bias since we only sampled 71 individuals in Jakarta, of which the majority were female. A more comprehensive anthropometric and clinical data is recommended for future studies to assess other obesity-related parameters (e.g., waist circumference, leptin levels).

\footnotetext{
Abbreviations

ARMS-PCR: Amplification-refractory mutation system-polymerase chain reaction; BMI: Body mass index; FTO: Fat mass and obesity-associated; HWE:
}

Hardy-Weinberg equilibrium; LD: Linkage disequilibrium; MAF: Minor allele frequency; MUFA: Monounsaturated fatty acid; PUFA: Polyunsaturated fatty acid; SAFA: Saturated fatty acid; SNPs: Single nucleotide polymorphisms.

\section{Supplementary Information}

The online version contains supplementary material available at https://doi. org/10.1186/s13104-021-05823-1.

Additional file 1: Table S1. Primers used for ARMS-PCR detection. Oligonucleotide sequences were obtained from Priliani et al. [42]. Fin: forward inner primer; Rin: reverse inner primer; Fout: forward outer primer; Rout: reverse outer primer. Table S2. Baseline characteristics of obese and non-obese subjects. Demographic, anthropometric, and dietary data are presented as mean \pm SD for normally distributed variables and median (Quantile 1-Quantile 3) for abnormally distributed data. Differences between groups assessed using t-test for normally distributed variables, or Mann-Whitney $U$ test for non-normal variables. Significant differences $(p<0.05)$ are marked in bold.

\section{Acknowledgements}

The authors would like to thank all volunteers who took part in this research. We expressed our gratitude to Mr. Farid Sastra Negara, SSi, and the Kalgen Innolab's technical staff for their assistance with blood collection and DNA extraction. We are grateful to Ms. Lindawati Wibowo, SSi, MSc. for her assistance in food categorization following the Food-based Dietary Guidelines of Southeast Asian Countries, and Widjaja Lukito, MD, PhD, for his insightful inputs.

\section{Authors' contributions}

SGM and IMA conceived and supervised the study. AA and LP performed the ARMS PCR. AA, LP, SO, and CAF, performed data analysis. MD collected the samples, clinical and dietary assessment. AA, LP, SO, and CAF wrote the original manuscript draft. AA, LP, SO, CAF, IMA, and SGM revised the manuscript. All authors read and approved the final manuscript.

\section{Funding}

The Eijkman Institute was funded by the Indonesian Government through the Indonesian Ministry of Research and Technology in 2020 (now National Research and Innovation Agency/Badan Riset dan Inovasi Nasional/BRIN).

Availability of data and materials

The dataset analyzed in this study is available upon reasonable request from the corresponding author.

\section{Declarations}

\section{Ethics approval and consent to participate}

The ethical approval had been granted from the Medical Research Ethics Committee of the Faculty of Medicine, Universitas Indonesia (No. 1137/UN2/ F1/ETIK/2017, protocol number 17-12-1212). Archived DNA samples were obtained from a previous study with written informed consent.

\section{Consent for publication}

Not applicable.

\section{Competing interests}

The authors declare that they have no competing interests.

\section{Author details}

${ }^{1}$ Department of Biochemistry, Faculty of Mathematics and Natural Sciences, Bogor Agricultural University, Kampus IPB Dramaga, Jl. Raya Dramaga, Bogor 16680, West Java, Indonesia. 'Eijkman Institute for Molecular Biology, Ministry of Research and Technology/National Research and Innovation Agency, J. Diponegoro No. 69, Jakarta 10430, Indonesia. ${ }^{3}$ Department of Nutrition, Faculty of Medicine, Universitas Indonesia/Cipto Mangunkusumo National General Hospital, Jakarta, Indonesia. 
Received: 26 June 2021 Accepted: 26 October 2021

Published online: 07 November 2021

\section{References}

1. World Health Organization [WHO]. Obesity and overweight Fact sheet. WHO. 2016. https://www.who.int/news-room/fact-sheets/detail/obesityand-overweight. Accessed 21 June 2021

2. World Obesity Federation [WOF]. Obesity: missing the $2025 \mathrm{global}$ targets. London: World Obesity Federation; 2020. https://data.worldobesi ty.org/publications/WOF-Missing-the-2025-Global-Targets-Report-FINALWEB.pdf. Accessed 24 June 2021.

3. Yang $\mathrm{Q}$, Xiao T, Guo J, Su Z. Complex relationship between obesity and the fat mass and obesity locus. Int J Biol Sci. 2017;13:615-29.

4. Indonesia Ministry of Health [Indonesia MoH]. Riskesdas 2007 [National basic health research 2007 report]. Indonesia: Indonesia Ministry of Health; 2007. http://labdata.litbang.kemkes.go.id/images/download/ laporan/RKD/2007/lap_rkd07.pdf. Accessed 11 Oct 2013.

5. Indonesia Ministry of Health [Indonesia MoH]. Riskesdas 2018 [National basic health research 2018]. Jakarta: Indonesia Ministry of Health; 2018. http://labdata.litbang.kemkes.go.id/images/download/laporan/RKD/ 2018/Laporan_Nasional_RKD2018_FINAL.pdf.

6. Vos T, Lim SS, Abbafati C, Abbas KM, Abbasi M, Abbasifard M, et al. Global burden of 369 diseases and injuries in 204 countries and territories, 1990-2019: a systematic analysis for the global burden of disease study 2019. Lancet. 2020;396:1204-22. https://doi.org/10.1016/S0140-6736(20) 30925-9.

7. Institute for Health Metrics and Evaluation [IHME]. Indonesia country profile. Institute for Health Metrics and Evaluation; 2019. http://www. healthdata.org/indonesia. Accessed 22 June 2021.

8. Kristina SA, Ahsan A, Faradiba F, Haulaini S. Health burden of overweight and obesity: mortality and years of life lost (YLL) of diseases in Indonesia. Pharm Sci Asia. 2021;48:285-90.

9. Frayling TM, Timpson NJ, Weedon MN, Zeggini E, Freathy RM, Lindgren $C M$, et al. A common variant in the FTO gene is associated with body mass index and predisposes to childhood and adult obesity. Science. 2007;316:889-94.

10. Scuteri A, Sanna S, Chen W-M, Uda M, Albai G, Strait J, et al. Genome-wide association scan shows genetic variants in the FTO gene are associated with obesity-related traits. PLoS Genet. 2007;3:e115.

11. Dina C, Meyre D, Gallina S, Durand E, Körner A, Jacobson P, et al. Variation in FTO contributes to childhood obesity and severe adult obesity. Nat Genet. 2007;39:724-6.

12. Peeters A, Beckers S, Verrijken A, Roevens P, Peeters P, Van Gaal L, et al. Variants in the FTO gene are associated with common obesity in the Belgian population. Mol Genet Metab. 2008;93:481-4. https://doi.org/10. 1016/j.ymgme.2007.10.011.

13. Andreasen $\mathrm{CH}$, Stender-Petersen KL, Mogensen MS, Torekov SS, Wegner $L$, Andersen G, et al. Low physical activity accentuates the effect of the FTO rs9939609 polymorphism on body fat accumulation. Diabetes. 2008;57:95-101. https://doi.org/10.2337/db07-0910.

14. Babenko V, Babenko R, Gamieldien J, Markel A. FTO haplotyping underlines high obesity risk for European populations. BMC Med Genom. 2019;12(Suppl 2):46.

15. Merra G, Gualtieri P, Cioccoloni G, Falco S, Bigioni G, Tarsitano MG, et al. FTO rs9939609 influence on adipose tissue localization in the Italian population. Eur Rev Med Pharmacol Sci. 2020;24:3223-35.

16. Rana S, Bhatti AA. Association and interaction of the FTO rs 1421085 with overweight/obesity in a sample of Pakistani individuals. Eat Weight Disord Stud Anorex Bulim Obes. 2020;25:1321-32. https://doi.org/10.1007/ s40519-019-00765-x.

17. Hebbar P, Abu-Farha M, Mohammad A, Alkayal F, Melhem M, Abubaker J, et al. FTO variant rs 1421085 associates with increased body weight, soft lean mass, and total body water through interaction with ghrelin and apolipoproteins in Arab population. Front Genet. 2019;10:1411.

18. Hotta K, Nakata Y, Matsuo T, Kamohara S, Kotani K, Komatsu R, et al. Variations in the FTO gene are associated with severe obesity in the Japanese. J Hum Genet. 2008;53:546-53. https://doi.org/10.1007/ s10038-008-0283-1.
19. Rees SD, Islam M, Hydrie MZI, Chaudhary B, Bellary S, Hashmi S, et al. An FTO variant is associated with Type 2 diabetes in South Asian populations after accounting for body mass index and waist circumference. Diabet Med J Br Diabet Assoc. 2011;28:673-80.

20. Zhao N-N, Dong G-P, Wu W, Wang J-L, Ullah R, Fu J-F. FTO gene polymorphisms and obesity risk in Chinese population: a meta-analysis. World J Pediatr. 2019;15:382-9.

21. Chiang K-M, Chang $\mathrm{H}-\mathrm{C}$, Yang $\mathrm{H}-\mathrm{C}$, Chen $\mathrm{C}-\mathrm{H}$, Chen $\mathrm{H}-\mathrm{H}$, Lee $\mathrm{W}-\mathrm{J}$, et al. Genome-wide association study of morbid obesity in Han Chinese. BMC Genet. 2019;20:97.

22. Merritt DC, Jamnik J, El-Sohemy A. FTO genotype, dietary protein intake, and body weight in a multiethnic population of young adults: a crosssectional study. Genes Nutr. 2018;13:4.

23. Doaei S, Kalantari N, Izadi P, Salonurmi T, Jarrahi AM, Rafieifar S, et al. Interactions between macro-nutrients' intake, FTO and IRX3 gene expression, and FTO genotype in obese and overweight male adolescents. Adipocyte. 2019;8:386-91. https://doi.org/10.1080/21623945.2019.16937 45.

24. Saber-Ayad M, Manzoor S, Radwan H, Hammoudeh S, Wardeh R, Ashraf $A$, et al. The FTO genetic variants are associated with dietary intake and body mass index amongst Emirati population. PLOS ONE. 2019;14: e0223808. https://doi.org/10.1371/journal.pone.0223808.

25. Qi Q, Downer MK, Kilpeläinen TO, Taal HR, Barton SJ, Ntalla I, et al. Dietary intake, FTO genetic variants, and adiposity: a combined analysis of over 16,000 children and adolescents. Diabetes. 2015;64:2467-76. https://doi. org/10.2337/db14-1629.

26. Mehrdad M, Doaei S, Gholamalizadeh M, Eftekhari MH. The association between FTO genotype with macronutrients and calorie intake in overweight adults. Lipids Health Dis. 2020;19:197.

27. Katus U, Villa I, Ringmets I, Vaht M, Mäestu E, Mäestu J, et al. Association of FTO rs 1421085 with obesity, diet, physical activity, and socioeconomic status: a longitudinal birth cohort study. Nutr Metab Cardiovasc Dis. 2020:30:948-59. https://doi.org/10.1016/..numecd.2020.02.008.

28. Daya M, Pujianto DA, Witjaksono F, Priliani L, Susanto J, Lukito W, et al. Obesity risk and preference for high dietary fat intake are determined by FTO rs9939609 gene polymorphism in selected Indonesian adults. Asia Pac J Clin Nutr. 2019;28:183-91.

29. Melhorn SJ, Askren MK, Chung WK, Kratz M, Bosch TA, Tyagi V, et al. FTO genotype impacts food intake and corticolimbic activation. Am J Clin Nutr. 2018;107:145-54. https://doi.org/10.1093/ajcn/nqx029.

30. Kühn AB, Feis D-L, Schilbach L, Kracht L, Hess ME, Mauer J, et al. FTO gene variant modulates the neural correlates of visual food perception. Neuroimage. 2016;128:21-31. https://doi.org/10.1016/j.neuroimage.2015. 12.049 .

31. Czajkowski P, Adamska-Patruno E, Bauer W, Fiedorczuk J, Krasowska U, Moroz $\mathrm{M}$, et al. The impact of FTO genetic variants on obesity and its metabolic consequences is dependent on daily macronutrient intake. Nutrients. 2020;12:3255. https://doi.org/10.3390/nu12113255.

32. Moleres A, Ochoa MC, Rendo-Urteaga T, Martínez-González MA, Julián MCAS, Martínez JA, et al. Dietary fatty acid distribution modifies obesity risk linked to the rs9939609 polymorphism of the fat mass and obesityassociated gene in a Spanish case-control study of children. Br J Nutr. 2012:107:533-8. https://doi.org/10.1017/S0007114511003424.

33. Tanaka T, Ngwa JS, van Rooij FJ, Zillikens MC, Wojczynski MK, Frazier-Wood AC, et al. Genome-wide meta-analysis of observational studies shows common genetic variants associated with macronutrient intake. Am J Clin Nutr. 2013;97:1395-402. https://doi.org/10.3945/ajcn.112.052183.

34. Stratigopoulos G, Burnett LC, Rausch R, Gill R, Penn DB, Skowronski AA, et al. Hypomorphism of Fto and Rpgrip 1 causes obesity in mice. J Clin Invest. 2016;126:1897-910.

35. Claussnitzer M, Dankel SN, Kim K-H, Quon G, Meuleman W, Haugen C, et al. FTO obesity variant circuitry and adipocyte browning in humans. N Engl J Med. 2015;373:895-907. https://doi.org/10.1056/NEJMoa1502214.

36. Lipoeto NI, Agus Z, Oenzil F, Wahlqvist ML, Wattanapenpaiboon N. Dietary intake and the risk of coronary heart disease among the coconut-consuming Minangkabau in West Sumatra, Indonesia. Asia Pac J Clin Nutr. 2004;13:377-84.

37. Hatma RD, Lukito W, Rumawas YSP. Fatty acids intake among diverse ethnic groups in Indonesia. Med J Indones. 2015;14:242-8.

38. Mancini A, Imperlini E, Nigro E, Montagnese C, Daniele A, Orrù S, et al. Biological and nutritional properties of palm oil and palmitic acid: effects 
on health. Molecules. 2015;20:17339-61. https://doi.org/10.3390/molec ules200917339.

39. Harika RK, Eilander A, Alssema M, Osendarp SJM, Zock PL. Intake of fatty acids in general populations worldwide does not meet dietary recommendations to prevent coronary heart disease: a systematic review of data from 40 countries. Ann Nutr Metab. 2013;63:229-38. https://doi.org/ $10.1159 / 000355437$.

40. World Health Organization Regional Office for the Western Pacific [WHO WRPO]. The Asia-Pacific perspective : redefining obesity and its treatment. 2000

41. Juergen Erhardt. NutriSurvey: nutrition surveys and calculations [computer software]. English. Germany: EBISpro; 2010. http://www.nutrisurvey. de/index.html.

42. Priliani L, Oktavianthi S, Hasnita R, Nussa HT, Inggriani RC, Febinia CA, et al. Obesity in the Balinese is associated with FTO rs9939609 and rs 1421085 single nucleotide polymorphisms. PeerJ. 2020;2020:1-15.

43. Sherry ST, Ward MH, Kholodov M, Baker J, Phan L, Smigielski EM, et al. dbSNP: the NCBI database of genetic variation. Nucleic Acids Res. 2001;29:308-11.

44. NCBI dbSNP. rs1421085 RefSNP report. 2021. https://www.ncbi.nlm.nih. gov/snp/rs1421085\#frequency_tab. Accessed 14 June 2021.

45. Tumonggor MK, Karafet TM, Hallmark B, Lansing JS, Sudoyo H, Hammer MF, et al. The Indonesian archipelago: an ancient genetic highway linking Asia and the Pacific. J Hum Genet. 2013;58:165-73. https://doi.org/10. 1038/jhg.2012.154.
46. Ma L, Xue Y, Liu Y, Wang Z, Cui X, Li P, et al. Polymorphism study of seven SNPs at ADH genes in 15 Chinese populations. Hereditas. 2005;142:103-11.

47. Harbron J, Van der Merwe L, Zaahl MG, Kotze MJ, Senekal M. Fat mass and obesity-associated (FTO) gene polymorphisms are associated with physical activity, food intake, eating behaviors, psychological health, and modeled change in body mass index in overweight/obese Caucasian adults. Nutrients. 2014;6:3130-52. https://doi.org/10.3390/nu6083130.

48. Yuzbashian E, Asghari G, Chan CB, Hedayati M, Safarian M, Zarkesh M, et al. The association of dietary and plasma fatty acid composition with FTO gene expression in human visceral and subcutaneous adipose tissues. Eur J Nutr. 2020. https://doi.org/10.1007/s00394-020-02422-x.

49. Shen J, Yang L, Wei W. Role of Fto on CaMKII/CREB signaling pathway of hippocampus in depressive-like behaviors induced by chronic restraint stress mice. Behav Brain Res. 2021;406: 113227. https://doi.org/10.1016/j. bbr.2021.113227.

50. Abdella HM, El Farssi HO, Broom DR, Hadden DA, Dalton CF. Eating behaviours and food cravings; influence of age, sex, BMl and FTO genotype. Nutrients. 2019;11:377. https://doi.org/10.3390/nu11020377.

\section{Publisher's Note}

Springer Nature remains neutral with regard to jurisdictional claims in published maps and institutional affiliations.
Ready to submit your research? Choose BMC and benefit from:

- fast, convenient online submission

- thorough peer review by experienced researchers in your field

- rapid publication on acceptance

- support for research data, including large and complex data types

- gold Open Access which fosters wider collaboration and increased citations

- maximum visibility for your research: over $100 \mathrm{M}$ website views per year

At BMC, research is always in progress.

Learn more biomedcentral.com/submissions 